\title{
Preparation and evaluation of kits for detection of antibodies of Pasteurella multocida
}

\author{
Zeinab M. Souror", A. A. Badawi, Hanan M. Ibarahim \\ Central Laboratory for Quality Control of Veterinary Biologics Abbassia, Cairo, Egypt
}

\begin{abstract}
Polyclonal hyperimmune serum against Pasteurella multocida type A:5, A:8 and A:9 was prepared in boskat rabbits. The indirect haemagglutination test (IHT) showed that such serum had an antibody titer of 1114. The immunoglobulins in the prepared antiserum were precipitated using saturated ammonium sulphate solution. Its concentration was adjusted to be $18 \mathrm{mg} / \mathrm{ml}$ in normal saline then it was conjugated with horse radish peroxidase and evaluated through the application of double sandwich ELISA. It was successful to detect Pasteurella multocida antibodies in positive serum samples with strong positive reactions up to a dilution of 1:100 of the prepared conjugate.
\end{abstract}

Pasteurellosis or fowl cholera is a serious disease problem facing poultry industry in Egypt (Gergis, 1978). It is caused by Pasteurella multocida which has been distinguished by somatic capsular serotyping (Rhoad and Rimler, 1986). On the other side, fowl cholera represents a respiratory disease facing avian population in dramatic forms which may lead to $100 \%$ mortalities. The disease is characterized by septicemia with high morbidity and mortality rates causing great economic losses (Birggs and Skeeles, 1984; Schlink and Olson, 1987). Diagnosis of fowl cholera depends mainly on the symptoms which occur in three forms: acute, subacute and chronic inflammation of the air passages and lungs and often end with death (Anon, 1961). In addition, the postmortem and histopathological findings play an important role in the diagnosis of the disease as the presence of degenerative ultrastructural changes in epithelial and endothelial cells of the lungs of infected birds (Al-Haddawi et al., 2000). More recent techniques were arise for detection of Pasteurella multocida antigen or antibodies as shown by Borkoska-Opacka et al. (1997) who used ELISA to measure the level of specific IgG to Pasteurella multocida in the sera of birds vaccinated against pasteurellosis. The present study was planned to prepare peroxidase labeled antibodies against Pasteurella multocida; as a local product; to be used for detection of fowl cholera using ELISA saving the long time and cost which usually in need to provide a native conjugate.

\section{Materials and Methods}

Rabbits. Eight apparently healthy adult boskat rabbits of about $3 \mathrm{~kg}$ body weight were used for preparation of polyclonal antibodies against Pasteurella multocida. These rabbits were found to be free from Pasteurella multocida infection and antibodies as detected by IHA test.

Bacterial strains. Pasteurella multocida serogroups 5-A, 8-A and 9-A standard strains were supplied by the Aerobic Bacteria Vaccine Research Department, Veterinary Serum and Vaccine Research Institute, Abbassia, Cairo. The colony forming unit for these strains was $3.25 \times 10^{10} / \mathrm{ml}$.

Preparation of Pasteurella multocida antigen. Pasteurella multocida antigen was prepared according to (Higgins and Whithear,1985).

Preparation of Pasteurella multocida hyperimmune serum. It was carried out according to (Green and Manson,1990).

Precipitation of immunoglobulin. The prepared immunoglobulin was precipitated using Ammoniu sulphate (Hopkin and Williams LTD, Chad Well Health, Essex, England) according to the method described by (Vogt, 1969). The globulin content was determined by the method described by Henry (1974) using Beckman DU7400 spectrophotometer. The concentration was adjusted to be $18 \mathrm{mg} / \mathrm{ml}$ in normal saline. Conjugation of anti-Pasteurella multocida globulin with horse radish_peroxidase. The obtained globulins were labeled with horse raddish peroxidase (Product No.P-8375 type VI, lot number 25C-9510, Sigma Chemical Com.) as described by Tijssen and Kurstak (1984) as

\footnotetext{
* Corresponding author. Tel.: +2023429204 (Zeinab. M. Souror)
} 
Table (1): Absorbance values of the double antibody sandwich ELISA.

\begin{tabular}{ccccc}
\hline Tested serum & \multicolumn{3}{c}{ Dilution of the prepared conjugate } \\
\cline { 2 - 5 } & Undiluted & $\mathbf{1 : 1 0}$ & $\mathbf{1 : 1 0 0}$ & $\mathbf{1 : 1 0 0 0}$ \\
\hline $\begin{array}{c}\text { Positive PM type 5-A } \\
\text { antiserum }\end{array}$ & 0.414 & 0.181 & 0.092 & 0.076 \\
$\begin{array}{c}\text { Positive PM type 8-A } \\
\text { antiserum }\end{array}$ & 0.419 & 0.250 & 0.110 & 0.090 \\
$\begin{array}{c}\text { Positive PM type 9-A } \\
\text { antiserum }\end{array}$ & 0.438 & 0.244 & 0.125 & 0.098 \\
\hline
\end{tabular}

The absorbance values were read at $450 \mathrm{~nm}$ wave length.

The limit of positive result is 0.0988 .

follow: 5mg of horse radish peroxidase (HRP) were dissolved in $1 \mathrm{ml}$ double distilled water followed by addition of $0.4 \mathrm{ml}$ of freshly prepared sodium periodate solution (Win Lab laboratory reagents for fine chemicals) with gentle steering for 20 minutes at room temperature till a greenish color was obtained. The $\mathrm{pH}$ was adjusted to be 9.5 by adding $0.25 \mathrm{ml}$ of $0.2 \mathrm{M} \mathrm{NaCO}_{3}$. $18 \mathrm{mg}$ of Pasteurella multocida immunoglobulin in $1 \mathrm{ml}$ normal saline were added to such solution and placed on a shaker for 2 hours at room temperature. $0.1 \mathrm{ml}$ of $4 \mathrm{mg} / \mathrm{ml}$ of sodium borohydrate (SD Fine Chemical LTD Scientific Company, Division Fair Lawn Jersey, USA) was added and the reaction was allowed to continue for 2 hours at $4^{\circ} \mathrm{C}$. The prepared conjugate was dialyzed against phosphate buffer solution and an equal volume of glycerol was added to it then stored at $-20^{\circ} \mathrm{C}$ till used.

Check board ELISA. It was done for titration of the prepared immuneperoxidase conjugated Pasteurella multocida immunoglobulin to detect the optimal antigen and antibody dilutions for plate coating according to (Rose et al.,1986). Enzyme Linked Immunosorbent Assay (ELISA). Double antibody sandwich ELISA was performed according to Voller et al. (1982) It was applied for detection and estimation of Pasteurella multocida antigen. Imported antiPasteurella multocida horse radish peroxidase conjugate (Sigma Company, USA.) was used as positive control.

Positive sera against Pasteurella multocida type 5-A, 8-A and 9-A. These antisera were supplied by the Central Laboratory for Quality Control of Veterinary Biologics, Abbassia, Cairo.

\section{Results and Discussion}

Pasteurellosis or fowl cholera is a serious respiratory disease representing a problem facing poultry industry in dramatic forms in Egypt (Gergis, 1978).

Diagnosis of fowl cholera depends mainly on the symptoms; postmortem and histopathological findings (Al-Haddawi et al., 2000). More recent techniques were arise for detection of Pasteurella multocida antigen or antibodies as shown by Borkosa-Opacka et al. (1997) who used ELISA to measure the level of specific IgG to Pasteurella multocida in the sera of birds vaccinated against pasteurellosis. From this point of view a local ELISA kit saving time and cost, should be available.

The obtained results showed that the prepared Pasteurella multocida hyperimmune serum showed titer of 1114.

Accurate precipitation of immune globulin in such preparation revealed that its concentration was $12.5 \mathrm{mg} / \mathrm{dl}$ which adjusted to be $18 \mathrm{mg} / \mathrm{ml}$ as recommended by Tijssen and Kurstak (1984) for further conjugation with horse radish peroxidase. Periodate method for conjugation was used where there is no interference between the enzymatic activity of the serum and the periodate (Nakane and Kawaoi 1974; Tijssen and Kurstak, 1984; Zeidan et al., 2000).

It was found that the optimal dilution of both of the imported and prepared Pasteurella multocida immune globulins conjugated with horse radish peroxidase was 1:100.

Depending on the obtained results Pasteurella multocida immunoglobulin conjugated with horse radish peroxidase is available and could be used for production of local ELISA kit that 
having the advantage of reduced cost with retaining sufficient sensitivity.

\section{References}

Al-Haddawi, M.H.; Jansi, S.; Zamri S.; Abd ElMutalib, A.R. and Sheikh Omar, A.R. (2000): Ultrastructural observation on nasal and pulmonary intra cellular Pasteurella multocida A:3 in rabbits. Vet.Commun.,24 (3): 153-167.

Anon (1961): Pasteurellosis. Merck Vet.Man. $2^{\text {nd }}$ ed. 342360.

Birggs, D. and Skeeles, J. K. (1984): An Enzyme Linked Immune Sorbent Assay for detection of antibodies to Pasteurella multocida in chickens. Avian Dis.,28 (1): 1724.

Borkoska-Opacka, B.; Kedrak, A. and Truszynski, M. (1997): Application of ELISA for determination of antiPasteurella multocida IgG in the sera of rabbits vaccinated against pasteurellosis under field conditions. Bull. Vet. Inst. Poulway, 41 (1): 17-24.

Gergis, S. M. (1978): Some immunizing properties concerning Pasteurella multocida in poultry. M. Vet. Sci. Thesis (Microbiology), Fac. Vet. Med., Cairo Univ.

Green, A. and Manson, M. M. (1990): Production of poly-clonal antisera. Immunochemical protocols, $2^{\text {nd }}$ ed. 80: $1-4$

Henry, R. J. (1974):Clinical chemistry principals and techniques. Harper and Row, New York: 411-420.
Higgins, P. A. and Whithear, K. G. (1985): Detection and differentiation of antibodies in chicken serum using ELISA. Avian Dis.,3 (1): 160-168.

Nakane, P.K. and Kawaoi, A. (1974): Peroxidase labeled antibody: A new method of conjugation. J. Histochem Cyto.,11:1084. Rhoad, K. R. and Rimler, R. B. (1986): Somatic serotypes of Pasteurella multocida isolated from avian hosts (1976-1988). Avian Dis., 34: 193-195.

Rose, N. R.; Friodman, H. and Fahey, J. L. (1986): Manual clinical laboratory immunology, $3^{\text {rd }}$ ed. Am. Soc. Microbiol. Washington, D.C.: 107-109.

Schlink, G. T. and Olson, L. D. (1987): Fowl cholera vaccination of growing turkeys with $\mathrm{CU}$ strain via routs other than oral. Avian Dis.,31 (1): 22-28.

Tijssen, P. and Kutstak, E. (1984): Highly efficient and simple method for the preparation of peroxidase and active peroxidase antibody conjugates for enzyme immune assays. Anal. Biochem. J., 136: 451-457.

Vogt, P. K. (1969): Immunoflourescent detection of viral antigens. Manual on the diagnosis in virology book (New York\& London) 316-326.

Voller, A.; Bidwell, D. E. and Bartlett, A. (1982): ELISA technique in virology. In C.R. Howard (ed.), New Developments in Practical Virology, New York; Alan R. Liss, pp.59-81.

Zeidan, S. M.; Abd El-Aty, M. M.; Kassem, E. A. and Deghaidy W. (2000): Preliminary studies for preparation of conjugated peroxidase antiserum against bovine viral diarrhea (BVD) virus. Beni Suef Vet.Med.J., (1): 113-125.

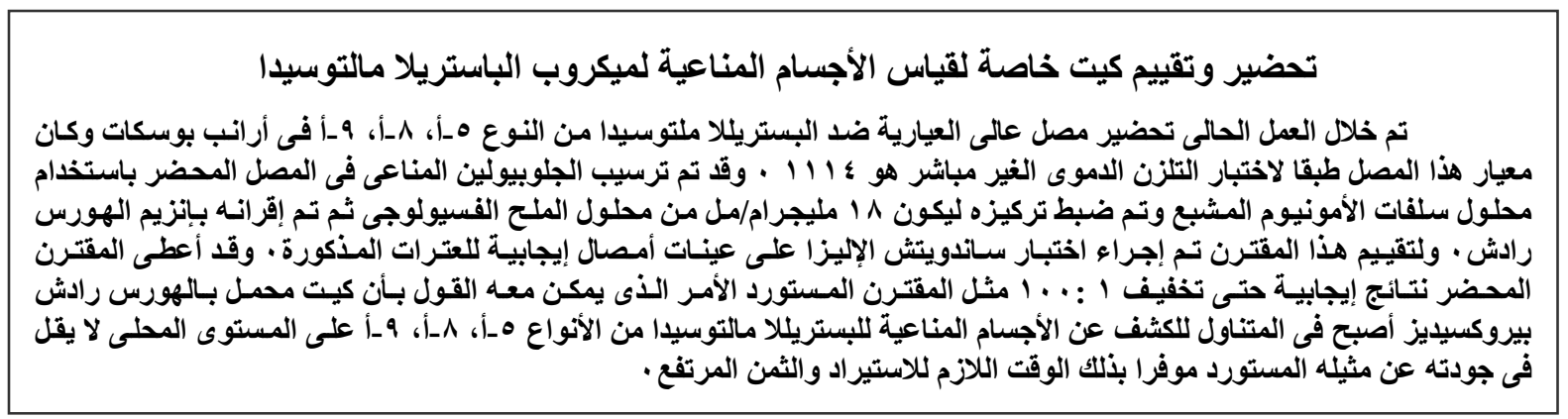

